\title{
Shifting in Tourism Policies and Issues Encountered by Tourists After The Emergence of Covid-19 Pandemic
}

\author{
Norsyaza Husna binti Albakeri ${ }^{1 *}$, Dyah Mutiarin ${ }^{2}$, Janianton Damanik ${ }^{3}$ \\ ${ }^{1,3}$ Gadjah Mada University \\ ${ }^{2}$ Mubammadiyah University of Yogyakarta \\ *norsyazabusna94@mail.ugm.ac.id
}

\begin{abstract}
Tourism policies act as a pillar to ensure that the sector is properly handled in accordance with its laws and regulations. However, the emergence of the 2019 corona virus novel had raised international concerns which had an impact on the psychological, physical, social and environmental aspects of society. This study used a qualitative method, where data collection was carried out using a systematic literature review (SLR) from various published papers related to tourism policy, tourist behavior, and Covid-19. The data analysis process will be assisted by the electronic software system NVivo and VOSviewer. This study aims to examine the shift in policy and tourism issues faced by tourists after the emergence of the sars-Cov-2 (covid19) virus which affects tourism behavior to ensure that tourists and tourism actors will meet with each other's current understanding. tourism patterns. Based on the results of the analysis, policy intervention does affect the shift in tourism behavior both from internal and external factors. Transitional problems faced by tourists have been identified from various external and internal aspects, such as limited choice of destinations, strict new policies, hidden travel costs, and people's mindsets.
\end{abstract}

Keywords: Covid-19, Tourism Issues, Travel, Psychology, Measures \& Policy 
Shifting in Tourism Policies and Issues Encountered by Tourists After The Emergence of Covid-19 Pandemic

\section{A. Introduction}

Travel culture exists since before the 21 st centuries which drives the tourism sector as one of the fastest-growing industries in the world. It has been contributing a tremendous percent to the development and GDP value of the country. Tourism is a social, cultural, and economic phenomenon that requires the movement of people to countries or places outside their usual environment either for personal, business, or professional purposes for not more than one consecutive year. These people are called visitors, which, can be either tourists or travelers; locals or non-locals. Tourism policy acts as a pillar in ensuring that the sector is handled properly per its laws and regulations. According to Shuraiki, (2002), tourism policy is the control methods that shows the government involvement in tourism development (economic, sociocultural, and environmental aspects) whereas tourism policy is a set of the resolution, discourse, and system pushed by governments in collaboration with private or social sectors (sometimes) in ensuring the diverse objective related to tourism development and industries were achieved (Velasco, 2020)

However, in 2019, the second Severe Acute Respiratory Syndrome which is known as SARS-CoV-2 or Covid19 virus was detected in Wuhan, China, before it was announced as a global pandemic in March 2020 (Muralidar et al., 2020). This occurring novel pandemic (SARS-CoV-2) has forced several countries to move their Emergency Response Team (ERT) into action by activating a higher level of public health measures to block the transmission of the virus among communities within the country (Parvez et al., 2020). The emergence of this pandemic outbreak has caused an international concern where it affects peoples' psychological state, physical, social, and environment. This pandemic has forced policy intervention in its management including Tourism Policy.

According to Glover, et al (2020), this intervention is intended to reduce the risk of transmission related to Covid19 and each country has chosen a different policy intervention according to its control measures (can be extreme or moderate intervention). Policy interventions lead to shifts in tourism practices to complement the current global situation and to ensure the safety and well-being of people. This shift in tourism policy has an impact on tourism patterns, tourist behavior and even makes people think twice about traveling. However, there are still people who want to travel because it helps them break away from their usual lifestyle and rebuild their minds. Therefore, what distinguishes this study from previous research is that this research specifically discusses:

1. Problems faced by tourists after the emergence of SARS-CoV-2 (Covid 19) when traveling, where the data analysis process will be assisted by the electronic system software NVivo and VOSviewer.

2. External and internal impacts of tourism policy interventions on the tourist experience.

Tourism Research Journal, Volume 5 (1), 2021 
Shifting in Tourism Policies and Issues Encountered by Tourists After The Emergence of Covid-19 Pandemic

\section{B. Literature Review}

The literature review from previous study related to tourism policy and issues encountered by tourist before and after the emergence of covid-19 can helps to provide a clear understanding and information regarding the research area. Therefore, several related article were reviewed and summarized into the table 1 below. The information gathered may helps to become a supporting data and references in this research.

Table 1. Shows The Summary of Literature Review Related to Tourism Policy and Issues

\begin{tabular}{|c|c|c|}
\hline Author & Year & Literature data \\
\hline \multicolumn{3}{|l|}{ Tourism Policy } \\
\hline $\begin{array}{l}\text { Association of } \\
\text { Caribbean States }\end{array}$ & 2015 & $\begin{array}{l}\text { - Tourism policy presents the vision and mission that } \\
\text { want to be achieved by tourism sector of one country. } \\
\text { Tourism policy states should be detailed, systematic and } \\
\text { clear to be able to act as a guide to all tourism actor } \\
\text { (AGC, 2015). }\end{array}$ \\
\hline Tarafa Shuraiki & 2002 & $\begin{array}{l}\text { Tourism policy basically found in a form of law and } \\
\text { regulation, official documents and procedures. It also } \\
\text { helps to guide the development in several aspects such } \\
\text { as economy, socio cultural and environment (Shuraiki, } \\
\text { 2002) }\end{array}$ \\
\hline Items & & Purposes/Benefits \\
\hline Economy & & $\begin{array}{l}\text { Persuade private/public sec-tor to encourage tourism dev- } \\
\text { elopment by: } \\
\text { 1. Enhance balance of payment situation. } \\
\text { 2. Regional development } \\
\text { 3. Economy diversity. } \\
\text { 4. Improve earning levels / state revenues. } \\
\text { 5. Job opportunities. } \\
\text { 6. Generates of non-tourism investment. }\end{array}$ \\
\hline Socio-Cultural & & $\begin{array}{l}\text { Promoting the socio-cultural benefits, such as, } \\
\text { 1. Cultural exchange } \\
\text { 2. Revival of traditional crafts and ceremonies } \\
\text { 3. Rural development, etc. } \\
\text { Protect social well-being by reducing tourism social- } \\
\text { cultural effects, such as, } \\
\text { 1. Deterioration of histori-cal and archaeological sites } \\
\text { 2. Social degradation, } \\
\text { 3. Overcrowding by tourists } \\
\text { 4. Loss of convenience for local residents, etc. }\end{array}$ \\
\hline Environment & & $\begin{array}{l}\text { Control/Reduce environme-ntal impact caused by } \\
\text { tourism activities either by poor planning or setting, such } \\
\text { as, } \\
\text { 1. Environmental Pollution }\end{array}$ \\
\hline
\end{tabular}

Tourism Research Journal, Volume 5 (1), 2021 
Shifting in Tourism Policies and Issues Encountered by Tourists After The Emergence of Covid-19 Pandemic

\begin{tabular}{|c|c|c|}
\hline \multicolumn{3}{|c|}{$\begin{array}{l}\text { 2. Other environmental haz-ards } \\
\text { 3. Land use problems }\end{array}$} \\
\hline Political & & $\begin{array}{l}\text { As in addition, government may also use tourism to } \\
\text { further the political object-ives. }\end{array}$ \\
\hline \multicolumn{3}{|c|}{ Issues Encountered by Tourist } \\
\hline $\begin{array}{l}\text { Madhavi } \\
\text { Chockalingam\& } \\
\text { A.Auroubindo } \\
\text { Ganesh }\end{array}$ & 2010 & $\begin{array}{l}\text { - There is none of the tourist who has zero circumstance } \\
\text { during travelling. Tourist basically will encounter either } \\
\text { problems related to CHSE or related to accommodation } \\
\text { and hospitality (Chockalingam \& Ganesh, 2010) }\end{array}$ \\
\hline $\begin{array}{l}\text { Danni Zheng, } \\
\text { Qiuju Luo, Brent } \\
\text { W. Ritchie }\end{array}$ & 2020 & $\begin{array}{l}\text { - However, after the emergence of Covid19, in which } \\
\text { people conduct a post-pandemic tourism, some } \\
\text { individuals start to generates the feeling of "travel-fear" } \\
\text { where they welcome the anxiety into themselves related } \\
\text { to going out for travel (Zheng et al., 2020). } \\
\text { - Moreover, this anxiety is not only developed among } \\
\text { tourist but also among host. According to Zheng, et al } \\
\text { (2020), tourist encounter discrimination while travelling } \\
\text { and local people has been looking at them as the virus } \\
\text { transmitter (those who cause the virus transmission). In } \\
\text { fact, this discrimination shown by local is basically also } \\
\text { due to the anxiety feeling that developed within } \\
\text { themselves that make them into being paranoid. }\end{array}$ \\
\hline
\end{tabular}

\section{Research Methodology}

This study will be using qualitative methods where the data will be gather by a systematic literature/library review (SLR) from a wide range of published papers related to tourism policy, tourist behaviour and Covid-19. A number of sources were used for references such as Scopus, Google Scholar, Research Gate, Elsevier, Science Direct, etc. These sources were used as a part of data collection procedure where the articles were gathered and uploaded in Mendeley to ease the import and export process into software system, Nvivo.

To ensure the relevancy of the research area, VOSviewer software was used to analyse the frequency of the selected research area in one of the reference site which is Scopus.com. The articles were selected by using the keywords of Tourist Behaviour in 10 year publication range (2010-2020). The finding presents the results of approximately 5987 documents. However, this study will be scoped down into social sciences field where generates about 3869 document results. The 3869 document results were then transferred into VOSviewer to measure the relevancy of the study. The articles with the keywords of Tourism Policy, Tourist Behaviour, Pandemic Covid 19 were then gathered and compiled into a word cloud that were generates using NVivo. 


\section{The research question includes:}

1. What are the issues face by tourist after the emergence of SARS-CoV-2 (Covid 19) while travelling?

2. What are the external and internal impact of tourism policy intervention towards tourist experience?

As aforementioned, this study also made use of electronic software system, NVivo to analyse the gathered articles as well as data from social and online media. This is because according to Awan (2016), NVivo allows the author to identify, generates, and identify the pattern that emerged within the articles according to research indicators. All the articles, social and media online gathered using visulaization tools Ncapture (NVivo extension) data were imported into NVivo for further analysis either in tabulation form or graphic visualization form.

\section{Results and Discussion}

Based on the articles gathered from Scopus.com, the electronic analysis system VOSviewer helps to extract the most focused and discussed topic in a research related to the keywords of Tourist Behaviour. The result shows that the study related to tourist behaviour is still relevant as the articles related to the keyword is still up to date (refer figure 1 and figure 2). The frequent study of this topic shows that there is an important factor and issues that becomes the concern among researchers especially in social sciences area.

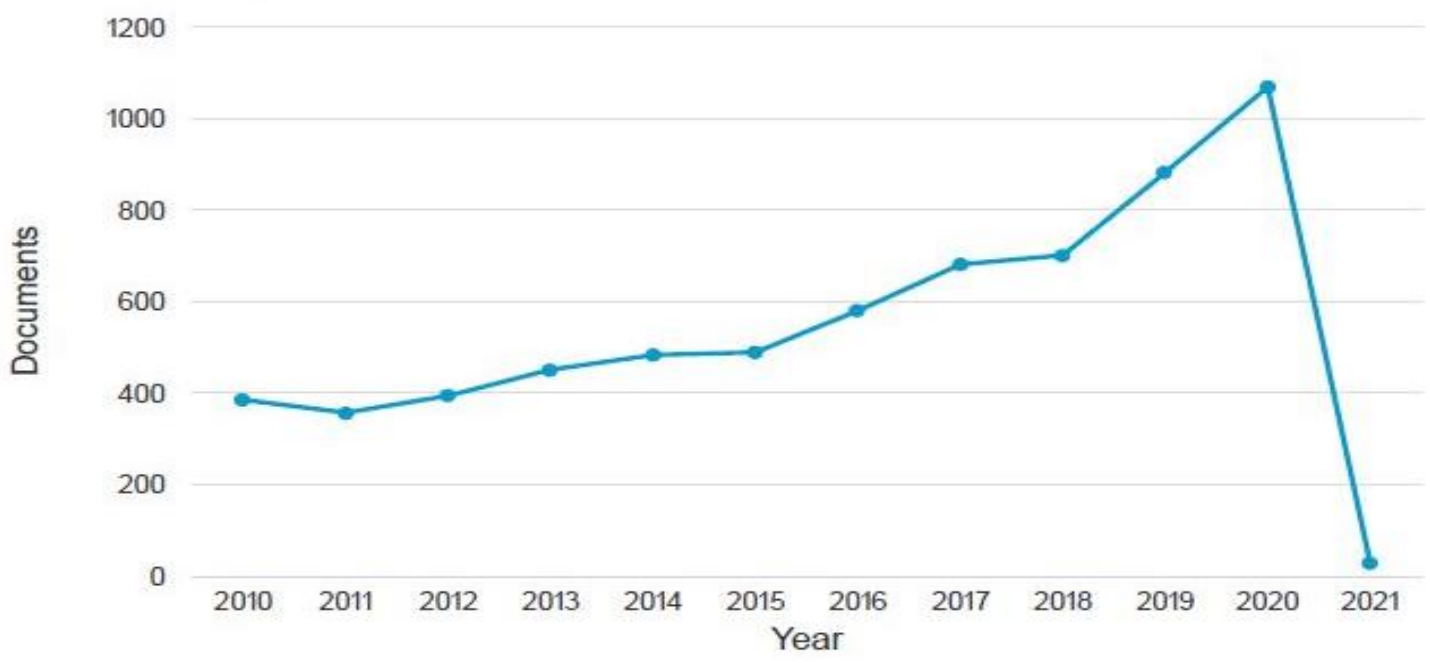

Figure 1. Line Graph Shows The Detected Documents Related To Tourist Behaviour By Year 
Shifting in Tourism Policies and Issues Encountered by Tourists After The

Emergence of Covid-19 Pandemic

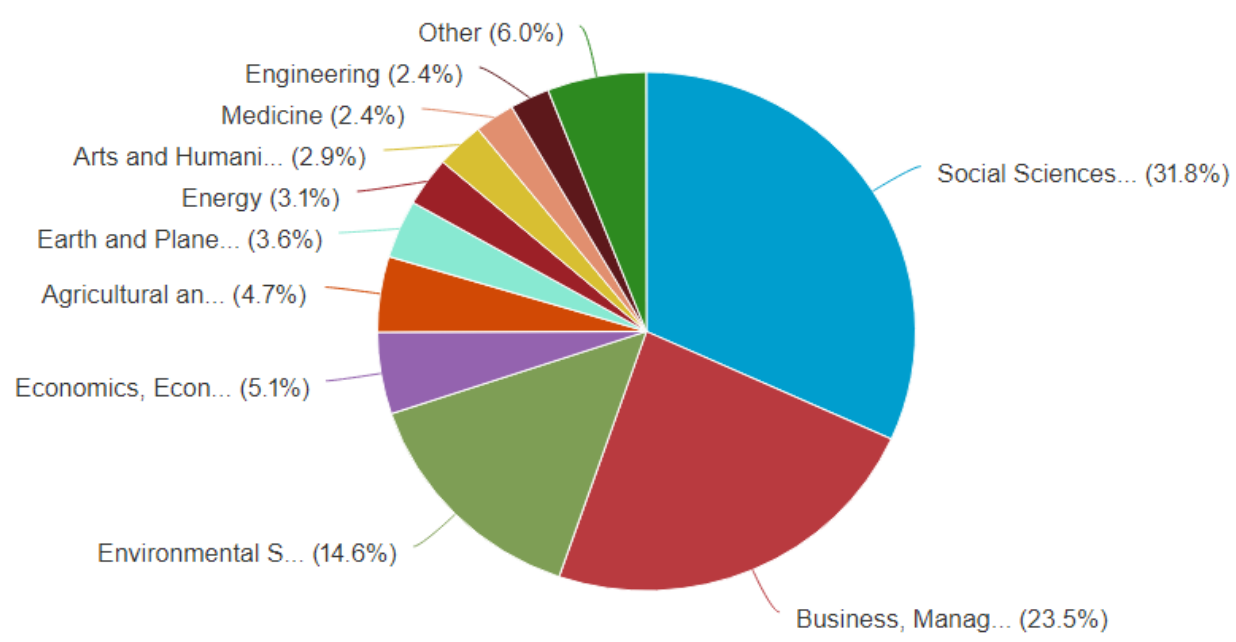

Figure 2. Pie Chart Shows The Research On Tourist Behaviour By Subjected Area

Figure 3. shows the result by VOSviewer software that generates from more than 3000 articles. The articles were then divided into 10 clusters representing the most mentioned words within the articles. The cluster were categorised in a table 2 below:

Table 2. Cluster Segregation By Vosviewer According To Items

\begin{tabular}{ll}
\hline CLUSTER & ITEMS \\
\hline Cluster 1 & $\begin{array}{l}\text { application authenticity, Covid, empirical study, framework, } \\
\text { involvement, pattern, protected area, tourist attraction, tourist } \\
\text { flow, Turkey, Poland, etc. }\end{array}$ \\
\hline Cluster 2 & $\begin{array}{l}\text { Challenge, customer satisfaction, determinant, Greece, } \\
\text { willingness, trust, demand, performances, etc. }\end{array}$ \\
\hline Cluster 3 & $\begin{array}{l}\text { Management, exploration, consequences, mobility, tourist } \\
\text { behaviour, tourist perception, vacation, etc. }\end{array}$ \\
\hline Cluster 4 & Ecotourism, opportunity, income, mouth, Italy, etc. \\
\hline Cluster 5 & $\begin{array}{l}\text { Happiness, life, motivation, outcome, inbound tourism, } \\
\text { international tourism, etc. }\end{array}$ \\
\hline Cluster 6 & Overtourism, destination loyalty, emotional solidarity, resident \\
& attitude, tourism development, etc. \\
\hline Cluster 7 & $\begin{array}{l}\text { Decision, demand, domestic tourist, Indonesia, Malaysia, travel } \\
\text { restriction, medical tourism, etc. }\end{array}$ \\
\hline Cluster 8 & Customer, revisit, tourist satisfaction, empirical analysis, etc. \\
\hline Cluster 9 & Crisis, tourist, constraint, risk perception, travel intention. etc. \\
\hline Cluster 10 & Length, stay
\end{tabular}

Tourism Research Journal, Volume 5 (1), 2021 
In line with the aforementioned table, figure 3 visualised the cluster into a word cluster that shows that most of author from the selected article (from Scopus.com) has wrote on tourism related to development, pattern, application, quality, tourist satisfaction and loyalty. The word cluster also shows the co-relation from one word to another on how tourism development can influence the destination loyalty and pattern, how word of mouth play a roles in decision process how tourism quality affect tourist satisfaction, and etc. The figure shows that each indicator will be affected by many factor either seen or hidden.

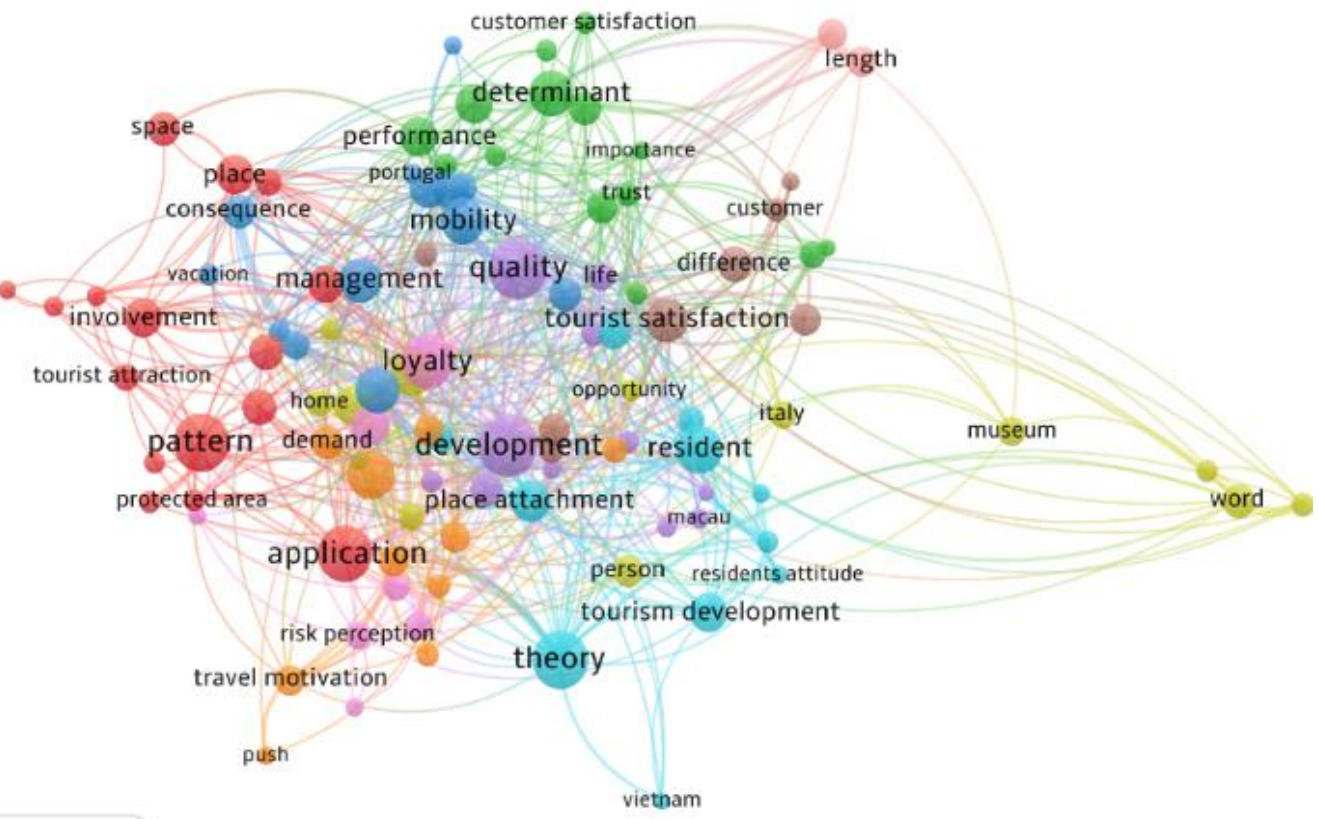

VOSviewer

Figure 3. Word Cluster representing the most discussed topic in existing articles

Based on the relevancy of the research generates using VOSviewer, the next electronic analysis software system, NVivo were used by gathering the articles related to tourism policy, tourism behaviour and pandemic of Covid 19. Approximately 20 articles were used in particular to generate the word cloud frequency, in which it helps the author to acquire the key words that were depicting tourist's behaviour in current phase of tourism policy intervention.

The result shows that out of 60 most common used words in the articles, there are 11 words that stood out, which are, travel, tourism, Covid, 2020, management, research, journal, social, people, risk, health, study and pandemic. Other than that, author also mentioned a lot within the 60 most common re-entered words is regarding emotions, perceived, distance, vaccines, crisis, etc. The key words is basically refers to measures and policy that was implemented in many country and industry during this pandemic of Covid19 phase.

Tourism Research Journal, Volume 5 (1), 2021 
Shifting in Tourism Policies and Issues Encountered by Tourists After The

Emergence of Covid-19 Pandemic

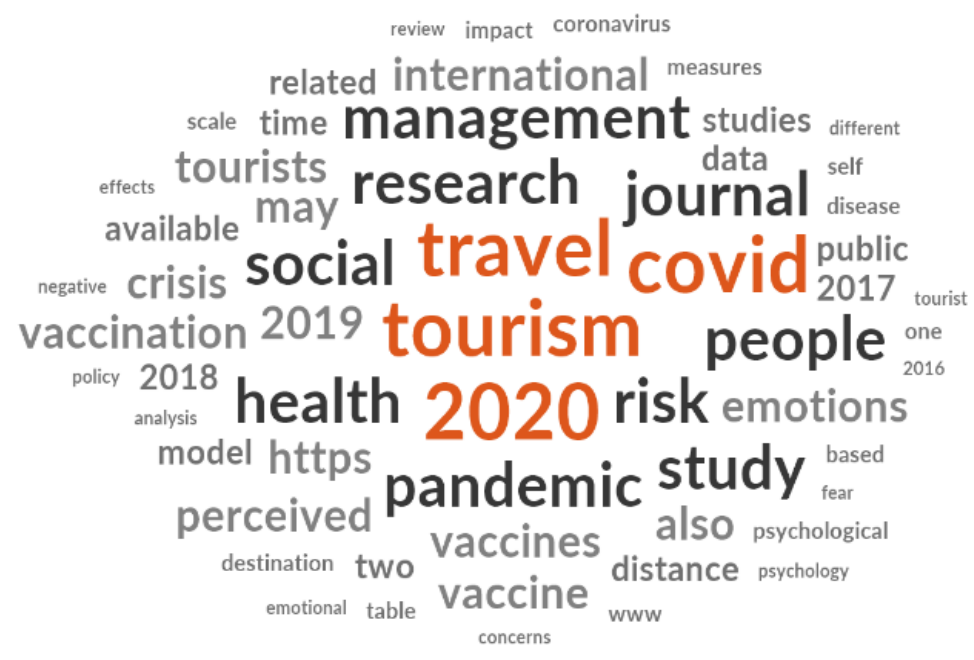

Figure 4. Word Cloud Representing The Most Common Re-Entered Words

The articles were then categorized into six major indicator which are Travel, Tourism, Tourist, Policy, Measures, psychological and pandemic (refer figure 5). From the indicators, this study will be able to relate the relation of each indicator to one another. For instance, the co-relation between travel and policy, tourism with measure, and etc. Interestingly, the term generates clearly shows that tourism, travel and the emergence of covid-19 can affect the emotions, psychological, tourist behavior as well as tourism management.

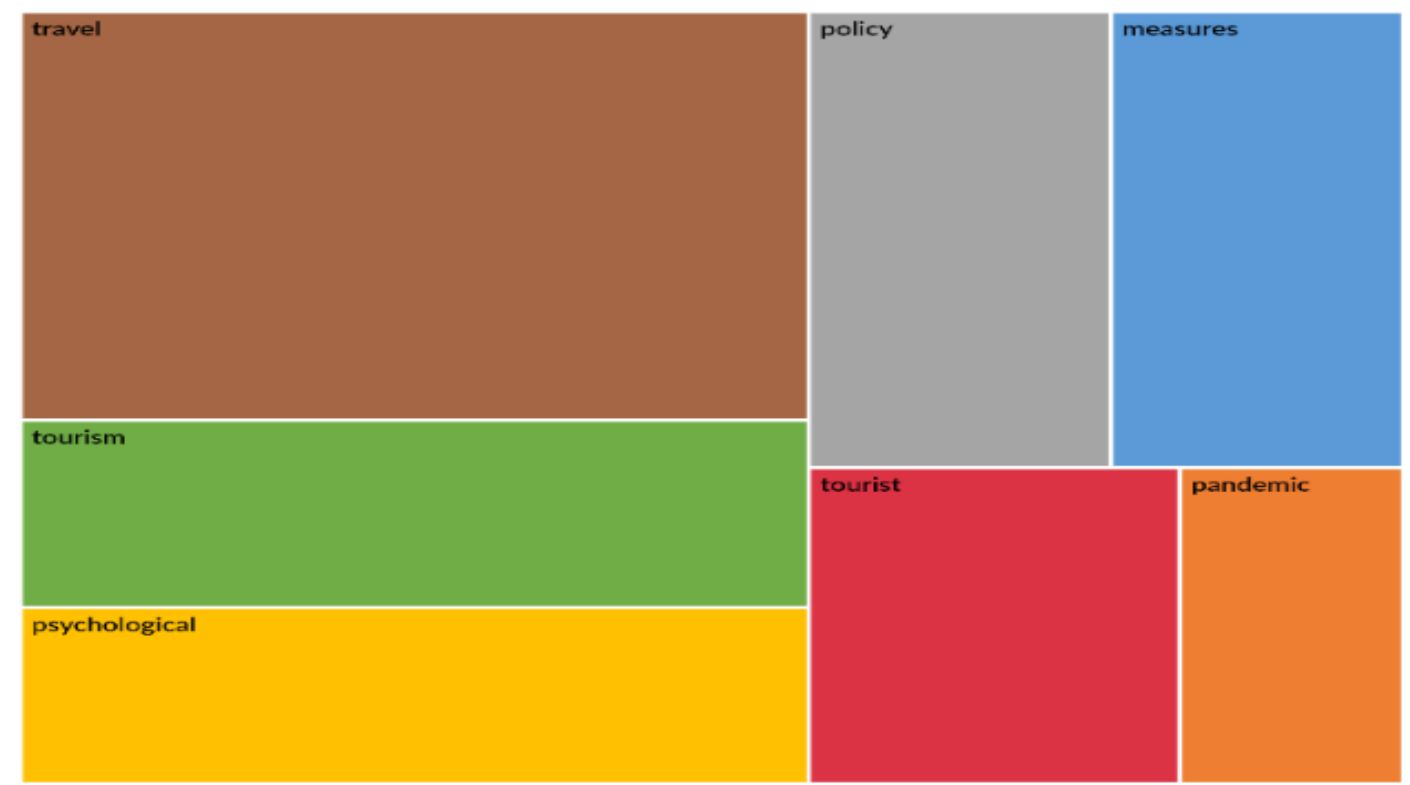

Figure 5. Hierarchy Charts Of Research Indicator

Tourism Research Journal, Volume 5 (1), 2021 
The main indicators were called as mother nodes in which they also consist of child nodes (refer figure 6). Figure 6 shows the linkages between each nodes, in which, indicator of tourist, policy, measures, travel and psychological has been circulated around one major indicator which is Tourism. Tourism act as the pillar that hold the other indicator and presents the relationship on how one another can be infected within tourism industry.

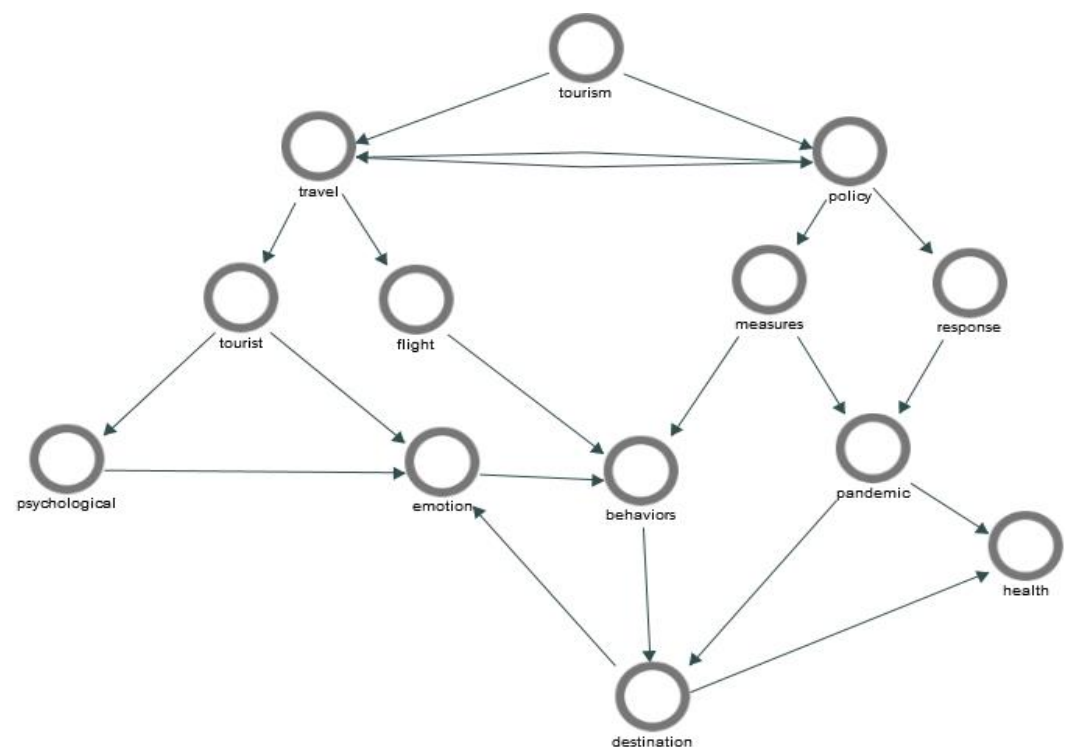

Figure 6: Word Cluster That Shows The Connection Of Each Indicator

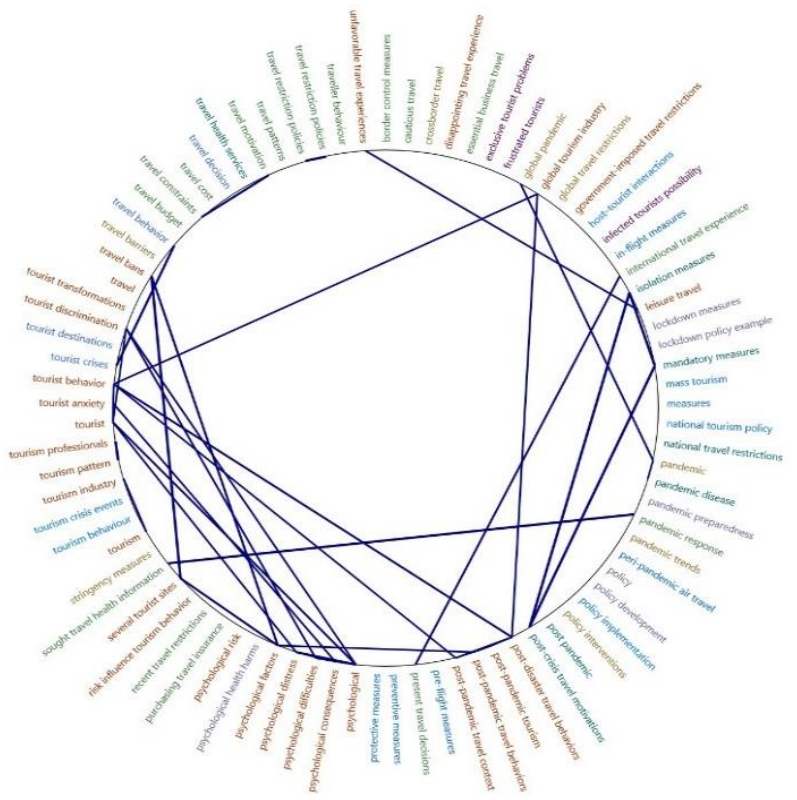

Figure 7. Item Clustered By Word Similarities

Tourism Research Journal, Volume 5 (1), 2021 
The finding shows that policy intervention influence the shifting in tourism behaviour in internal as well as external factor. The transition problems faced by tourists can indeed be seen in several external and internal aspects, such as limited destination choices, new strict policies to follow, hidden travel costs, and state of mind.

\section{Limitation of Destination Choices}

Due to Covid19 pandemic, every country starts to take an action to reduce and block the disease infection and transmission within their territory. According to Glover, et al (2020), countries has response to covid-19 outbreak differently depends on their governance which every and each country choosing different policy intervention in dealing with this issues. Therefore, we can see in our own country and even in the global news that some country has implement the lockdown in their country where they did not allow any arrival or departure from their territory. For example, in Malaysia the government has been implementing the lockdown and movement restriction order by stages. At the early stages communities were restricted from travelling as the border of each states were close and communities were not allowed to cross the border for the stated period. In addition, the number of people that can left home were controlled by one person per car and later increased to two person per car and they are not allowed to stay outside their house after 12 o'clock in the morning (24:00).

From this policy intervention, we can see that tourism industry definitely affected by this pandemic outbreak. By having the border closed and movement restriction order, the tourism destination surely won't be occupied by the tourist. Even though after the movement restriction order has been loosen up, tourist still face with the limitation in their destination choices. This is because during the covid19 outbreak some businesses has closed down permanently or temporarily. Hence, the choices of tourism destination is reducing. According to Nair \& Sinha (2020), the issues has become complicated especially in tourism decision making process including in choosing tourism destination. The limitation happened because of the complexity of the outbreak when some of the country might be recovering and some is still on its peak. Therefore, tourist who has been longing to travel and have an escape from their daily lifestyles might need to scope down their destination choices based on the situation of the destination area.

\section{Strict Policy to be Followed}

As the aforementioned, each country has been dealing with this pandemic differently either by a total lockdown, SOPs' implementation, Movement Control Order (MCO), etc. However, World Health Organisation (WHO) has come out with a general guidelines to be implement by all country in order to ensure the safety of their people as well as the effort to stop or reduce the number of disease transmission globally are successful.

Tourism Research Journal, Volume 5 (1), 2021 
Based on the news and personal observation we can see that travel and tourism sector has been severely affected compared to other industry during this pandemic outbreak. As time goes by, tourism industry started to get on their feet again after travel restriction have been lifted. Thus, the sectors begin to implement all the strict standard operation procedure (SOP), policy and protocol in their sector to ensure that tourism sector can be operate again. Most of the tourism destination reopening welcomes local and international tourist with the assurance that their safety will be assured. For example in Maldives, most tourism destination welcome the tourist with the assurance that their government has already ensure the implementation of a strict safety and hygiene standards (Darbari, 2020) in each tourism destination.

Strict policy nevertheless cause the shifting in tourism behaviour. This is because, tourist need to go through a "trivial" process in order to have their vacation or tour. According to Centers for Disease Control and Prevention, (2020), several additional process need to be taken from the moment they wants to board in the flight until the end of their tour or trip. Table 3. below will show the overview of procedures that need to be consider by those who wants to travel outside their country.

Table 3. Shows Additional Procedures That Should Be Considered During PostPandemic Tourism

\begin{tabular}{lll}
\hline When & 1. & Ensure to check travel restrictions \\
\cline { 2 - 3 } $\begin{array}{l}\text { decided } \\
\text { to travel }\end{array}$ & 2. & Get flu shot to avoid the potential from getting infe-cted \\
\cline { 2 - 3 } $\begin{array}{l}\text { During } \\
\text { travel }\end{array}$ & $\begin{array}{l}\text { Planned on the destination to visit (know their trans-mission } \\
\text { rate) }\end{array}$ \\
\hline & $\begin{array}{l}\text { 1. } \\
\text { Abide to all the SOP's honestly (use hand saniti-zer, practice } \\
\end{array}$ & $\begin{array}{l}\text { s. } \\
\text { 2. Avoial distanc-ing, wear face mask. Etc.) }\end{array}$ \\
\hline After travel & Avoid ceremonies or pla-ces with lots of people \\
\cline { 2 - 3 } & 2. & get swab test/health check even of do not have symp-toms \\
\cline { 2 - 3 } & $\begin{array}{l}\text { 3. } \\
\text { keep practicing the SOP's in daily activities/life (san-itize } \\
\text { frequently, practice social distancing, wear face mask and etc.) }\end{array}$ \\
\hline
\end{tabular}

In addition, travelling within country also requires the strict policy to be abide by tourist. Each and every tourism destination provides tourist with sanitizer, require the use of facemask also practicing social distancing within the accommodation, shops or restaurant. Therefore, this phenomenon might be a little bit drastic to tourist in adjusting themselves according to new normal due to Covid19 pandemic.

\section{Travel Cost Increment}

Due to the new normal phenomenon of Covid-19 era, people tend to think twice to travel as they need to abide to a strict regulation and protocol. This is because, the procedures that need to be followed might cost more in their travel budget as they

Tourism Research Journal, Volume 5 (1), 2021 
need to pay for swab test, hotels for quarantine, enough supply of basic necessities (facemask, hand sanitizer, etc.) and other supporting procedures to ensure that their tour is safe, enjoyable as well as did not become the course of the disease transmission.

According to Gek (2020), Singapore, for those who plan a round trip travel must contend with the Covid test. However, the price of the test could exceed the amount or price of their airplane ticket or could be more. Furthermore, the travellers might as well need to conduct a 14 day quarantine and require to bear full payment of the hotels. It is even costly if the person in not a local residents. This situation make people do the sums and aware that travel during post-Covid situation can be pricey or costly (Gek, 2020).

\section{Local and Tourist State of Mind}

As claimed by Zheng, et al (2020), the pandemic issue caused people to develop anxiety towards meeting people, moving places and this can be defined as "travel fear" among tourist. Travel fear is cause by an anxiety, fear and panic in the thought of getting infected by having a contact intentionally or unintentionally with other people. The fear of epidemic could affect people state of mind for a long time which can trigger the tourism and communication behaviours during and after the pandemic. One of the current factor that activate the travel fear within tourist is because of hygiene concerns lockdown implementation and rules of quarantine that need to be abide.

However, this travel fear is not necessarily attack the tourist or travellers, it can also attack the local. The travel fear among locals can happened when they have fear to welcome the tourist into their territory and discrimination towards tourist might happened. This can be seen from tourist state of mind where they might feel guilty at the same time developed anxiety when their visit is not warmly welcomed by the locals. Some tourist encountered with an unfortunate memories during the tour. This is because, they were treated like a moving virus that might transmit the disease to the local people. This treatment and discrimination eventually becomes the bad influence to people state of mind, in which, the effect might worsen from fear to anxiety to trauma.

Thus, state of mind will definitely affect tourism behaviour where the services provided and local interaction might not be as lively as before. Meanwhile, the experienced gain by tourist also will not be as rich as before post-Covid situation since the industry is still in the process of adjusting their services towards tourist as well as host.

\section{E. Conclusion}

This study attempted to examine the shifting in tourism policies and issues faced by tourist after the emergence of virus SARS-CoV-2 (Covid19). Based on this research it is clear that shifting and intervention in tourism policy has led to shifting in issues encountered by tourist as well. There is a lot of new additional procedures 
Shifting in Tourism Policies and Issues Encountered by Tourists After The Emergence of Covid-19 Pandemic

that need to be followed. Furthermore, the emergence of Covid19 also limit the tourist destination choice during this post-pandemic tourism.

In conclusion, the results clearly shows the correlation between tourism and pandemic with travel, policy, measures restriction, psychological towards the tourist. Therefore, the issues encountered by tourist should be brought into discussion by the responsible parties as it might help to improve the management and development of tourism sector during this post-pandemic situation.

Thus, it is hope that the findings might help the related sector in being enlighten on the issues faced by tourist on account of policy intervention (shifting) and led them to further research related to strategies for crisis preparedness in dealing with tourism issues, or tourism policy responses to address tourists' issues during post -pandemic situation and etc.

\section{REFERENCES}

AGC. (2015). The Crucial Role of a Tourism Policy in Enhancing Tourism Activity within the Region. Retrieved December 16, 2019, from http://www.acsaec.org/index.php?q=press-center/releases $/ 2015 /$ the-crucial-role-of-atourism-policy-in-enhancing-tourism-activity-within.

Awan, I. (2016). Islamophobia on Social Media: A Qualitative Analysis of The Facebook's Walls of Hate. International Journal of Cyber Criminology, 10(1): 1-20.

Centers for Disease Control and Prevention. (2020). Domestic Travel During the COVID-19 Pandemic. Retrieved June 10, 2019, from https://www.cdc.gov/coronavirus/2019-ncov/travelers/travel-during-covid 19.html.

Chockalingam, M., \& Ganesh, A. A. (2010). Problems Encountered by Tourists. Business and Economic Horizons, 3(3): 68-72.

Darbari, R. (2020). Travel and Tourism Recovery: A Perspective For South Asia and Lessons For Other Regions In The Age of COVID-19. Retrieved August 27, 2019, from https://www.weforum.org/agenda/2020/08/travel-and-tourism-recoverysouth-asia-covid19-pandemic-economy-india-nepal-bhutan-sri-lanka.

Gek, T. P. (2020). Swab Tests For That Overseas Trip Could Cost More Than The Return Plane Ticket, Business Time.Com. Retrieved July 5, 2019, from https://www.businesstimes.com.sg/consumer/swab-tests-for-that-overseastrip-could-cost-more-than-the-return-plane-ticket

Glover, R. E., Van Schalkwyk, M. C. I., Akl, E. A., Kristjannson, E., Lotfi, T., Petkovic, J., Petticrew, M. P., Pottie, K., Tugwell, P., \& Welch, V. (2020). A Framework for Identifying and Mitigating The Equity Harms of COVID-19 Policy Interventions. Journal of Clinical Epidemiology, 128: 35-48.

Muralidar, S., Ambi, S. V., Sekaran, S., \& Krishnana, U. M. (2020). The emergence of COVID-19 as a Global Pandemic: Understanding The Epidemiology, Immune Response and Potential Therapeutic Targets of SARS-CoV-2. Public

Tourism Research Journal, Volume 5 (1), 2021 
Health Emergency COVID-19 Initiative, 179: 85-100.

Nair, B. B., \& Sinha, S. (2020). COVID-19 and Future Travel Decisions: How do the Destination-Choice-Based Motivators Redefined Tourist Choices?. Enlightening Tourism a Pathmaking, 10(2): 306-322.

Shuraiki, T. (2002). Tourism Policy. Polityka Gospodarcza, 5(6): 274-283.

Parvez, M. K., Jagirdar, R. M., Purty, R. S., Venkata, S. K. S., Agrawal, V., Kumar, J., \& Tiwar, N. (2020). COVID-19 pandemic: Understanding The Emergence, Pathogenesis and Containment. World Academy of Sciences Journal, 2(18): 1-11.

Velasco, M. (2020). Global Encyclopedia of Public Administration, Public Policy, and Governance. Switzeland: Springer Link.

Zheng, D., Luo, Q., \& Ritchie, B. W. (2020). Afraid to travel after COVID-19? SelfProtection, Coping and Resilience Against Pandemic 'Travel Fear'. Tourism Management, 83: 1-13. 